\title{
Prediction of direct and indirect genetic gains and genotypic correlations in rubber tree progenies
}

\author{
Cecília Khusala Verardi(1), Erivaldo José Scaloppi Junior( ${ }^{(2)}$ and Paulo de Souza Gonçalves( ${ }^{(1)}$
} ${ }^{(1)}$ Instituto Agronômico, Programa Seringueira, Caixa Postal 28, CEP 13012-970 Campinas, SP, Brazil. E-mail: ckverardi@yahoo.com.br,
paulog@iac.sp.gov.br (2)Agência Paulista de Tecnologia dos Agronegócios, Pólo Regional Noroeste Paulista, Caixa Postal 61, CEP 15500-970
Votuporanga, SP, Brazil. E-mail: scaloppi@apta.sp.gov.br

\begin{abstract}
The objective of this work was to estimate the genetic parameters, genotypic and phenotypic correlations, and direct and indirect genetic gains among and within rubber tree (Hevea brasiliensis) progenies. The experiment was set up at the Municipality of Jaú, SP, Brazil. A randomized complete block design was used, with 22 treatments (progenies), 6 replicates, and 10 plants per plot at a spacing of $3 \times 3 \mathrm{~m}$. Three-year-old progenies were assessed for girth, rubber yield, and bark thickness by direct and indirect gains and genotypic correlations. The number of latex vessel rings showed the best correlations, correlating positively and significantly with girth and bark thickness. Selection gains among progenies were greater than within progeny for all the variables analyzed. Total gains obtained were high, especially for girth increase and rubber yield, which were 93.38 and $105.95 \%$, respectively. Young progeny selection can maximize the expected genetic gains, reducing the rubber tree selection cycle.
\end{abstract}

Index terms: Hevea brasiliensis, direct and indirect method, early selection, selection cycle.

\section{Predição de ganhos genéticos diretos e indiretos e correlações genotípicas em progênies de seringueira}

\begin{abstract}
Resumo - O objetivo deste trabalho foi estimar os parâmetros genéticos, as correlações genotípicas e fenotípicas, e os ganhos genéticos diretos e indiretos entre e dentro de progênies de seringueira (Hevea brasiliensis). O experimento foi instalado no Município de Jaú, SP. Utilizou-se o delineamento de blocos ao acaso, com 22 tratamentos (progênies), 6 repetições e 10 plantas por parcela, no espaçamento de $3 \times 3 \mathrm{~m}$. Progênies de três anos de idade foram avaliadas quanto ao perímetro do caule, à produção de borracha e à espessura de casca, pelo método de ganhos diretos e indiretos e por correlações genotípicas. A variável que apresentou as melhores correlações foi o número de anéis dos vasos laticíferos, que se correlacionou positiva e significativamente com perímetro do caule e espessura de casca. Os ganhos de seleção entre progênies foram maiores que dentro de progênies, para todas as variáveis avaliadas. Os ganhos totais obtidos foram altos, principalmente para incremento do caule e produção de borracha, com valores de 93,38 e 105,95\%, respectivamente. A seleção de progênies jovens pode maximizar os ganhos genéticos, o que reduz o ciclo de seleção da seringueira.
\end{abstract}

Termos para indexação: Hevea brasiliensis, método direto e indireto, seleção precoce, ciclo de seleção.

\section{Introduction}

Rubber tree [Hevea brasiliensis (Willd. ex Adr. de Juss.) Muell. Arg.] genetic breeding has a very long selection cycle, which can reach up to 30 years. Therefore, it is important to carry out studies on young plants using early analysis methods in progeny tests. These studies can be used to predict the genetic variability and selection gains of the studied population and as a basis for future breeding programs to reduce the breeding cycle of the species.

In order to reduce the selection cycle, it is necessary to develop methods for early selection and to assess parental potential in research involving secondary plant traits to estimate the relationship with latex yield (Gonçalves et al., 2001; Priyadarshan et al., 2009). Selecting traits in the juvenile stage may be an efficient method to reduce the breeding cycle and to maximize genetic gains (Adams et al., 2007). In early selection, traits are assessed at ages prior to rotation, and economically important traits are used as predictors at the rotation age. Early selection has been advantageous in terms of genetic gain per unit time (Rezende et al., 1994; Farias Neto et al., 2003). Thus, information on gain selection can be used to orient 
breeding programs more effectively in predicting the success of the selective plan adopted and in deciding, on a scientific basis, on alternative techniques that may be more effective (Cruz et al., 2004).

An important practice in breeding is selecting superior phenotypes, individuals or families, that make breeding viable, since selection and recombination must be made at individual and family levels to obtain bred populations (Martins et al., 2001). According to Paula et al. (2002), the possibility of predicting gains is considered one of the greatest contributions to breeding. When different criteria are considered, gain prediction for each criterion is fundamental, because it guides the breeders on how to best use the genetic material available in order to obtain maximum gains for the characters of interest.

Direct selection among and within progenies is an alternative, since it allows for the selection of the best progenies and individuals within them. However, in this type of approach, superior individuals of intermediate progenies or intermediate individuals of superior progenies may not always be considered in the selection (Freitas et al., 2009).

The objective of this work was to estimate the genetic parameters, the genotypic and phenotypic correlations, and the direct and indirect genetic gains among and within rubber tree progenies.

\section{Materials and Methods}

Twenty-two half-sib progenies, obtained from 22 parental clones phenotypically selected from a $H$. brasiliensis population from Asia, established at the Centro Experimental Central (CEC) of Instituto Agronômico (IAC), SP, Brazil, were used. To establish the progeny tests, seeds were collected at the CEC and placed in polyethylene bags, germinated and taken to the field when they had at least two open leaves. The experiment was set up at the Pólo Regional de Jaú $\left(22^{\circ} 17^{\prime} \mathrm{S}, 48^{\circ} 34^{\prime} \mathrm{W}\right.$, at $580-\mathrm{m}$ altitude), belonging to Agência Paulista de Tecnologia de Agronegócios, SP, Brazil. The terrain is flat, with a Rhodic Hapludox soil type (Latossolo Vermelho distrófico típico), with a sandy clay texture. The mean annual temperature and annual rainfall were $21.6^{\circ} \mathrm{C}$ and $1,344 \mathrm{~mm}$, respectively.

A randomized complete block design was used, with 22 treatments (progenies), six replicates, and ten plants per plot at a spacing of $3 \times 3 \mathrm{~m}$. Three-year-old progenies were assessed for girth, rubber yield, and bark thickness by direct and indirect gains and genotypic correlations.

Dry rubber yield (g per plant) was obtained by the Hamaker Morris-Mann (HMM) test, modified for three-year-old plants. The mean yield of 30 cuts per plant was used. The panels were opened $15 \mathrm{~cm}$ above ground level, with half-spiral tapping every three days for a total of 35 tappings. The first five tapping samples, which corresponded to the "panel adjustment" phase, were discarded. Girth $(\mathrm{cm})$ was determined at $50 \mathrm{~cm}$ above ground level, using a caliper rule.

To determine bark traits, two samples were collected per plant, $50 \mathrm{~cm}$ above ground level, using a punch. The samples were measured for bark thickness using a digital caliper rule. Other bark characteristics were determined using a microscope at the laboratory at IAC. To count the number of latex vessel rings, bark samples were first blocked in histological paraffin. Using radial longitudinal cuts, the number of rings was counted, the mean diameter $(\mu)$ of the vessels contained in the rings was observed in cross section cuts, and the mean distance $(\mu)$ between the consecutive latex vessel rings was determined based on all the rings.

The variables were analyzed by the mathematical model, $\mathrm{Y}_{\mathrm{ijk}}=\mu+\mathrm{p}_{\mathrm{i}}+\mathrm{b}_{\mathrm{j}}+\varepsilon_{\mathrm{ij}}+\mathrm{d}_{\mathrm{ijk}}$, which considered all the random effects, in which: $Y_{\mathrm{ijk}}$ is the observation for plant $\mathrm{k}$ in replicate $\mathrm{j}$, in progeny $\mathrm{i} ; \mu$ is the general mean; $p_{i}$ is the random effect of the $i$-eth progeny $(I=1,2, \ldots$, $p) ; b_{j}$ is the effect of replicate $j(j=1,2, \ldots, b) ; \varepsilon_{i j}$ is the effect of the random and experimental error associated to the ij plot; $d_{i j k}$ is the random deviation inherent to plant k within ij plot.

The means of plots in each location were used to obtain variance estimates (Table 1), according to

Table 1. Analysis of variance and expectation of 22 rubber tree progenies.

\begin{tabular}{lccc}
\hline $\begin{array}{l}\text { Source of } \\
\text { variation }\end{array}$ & DF & $\begin{array}{c}\text { Mean } \\
\text { squares }\end{array}$ & $\begin{array}{c}\text { Expetaction of } \\
\text { mean squares }\end{array}$ \\
\hline Blocks & $\mathrm{r}-1$ & - & - \\
Progenies & $\mathrm{p}-1$ & $\mathrm{MS}_{1}$ & $\sigma_{\mathrm{d}}^{2}+\mathrm{n} \sigma_{\mathrm{e}}^{2}+\mathrm{n} \sigma_{\mathrm{p}}^{2}$ \\
Among & $(\mathrm{r}-1)(\mathrm{p}-1)$ & $\mathrm{MS}_{2}$ & $\sigma_{\mathrm{d}}^{2}+\mathrm{n} \sigma_{\mathrm{e}}^{2}$ \\
Within & $\mathrm{rp}(\mathrm{n}-1)$ & $\mathrm{MS}_{3}$ & $\sigma_{\mathrm{d}}^{2}$ \\
\hline
\end{tabular}

$\sigma_{\mathrm{p}}^{2}$, mean genetic variance among progeny; $\sigma_{\mathrm{d}}^{2}$, genetic variance among plants within plot; $\sigma_{\mathrm{e}}^{2}$, variance of the experimental error among plots; $r, p$, number of repetitions and progenies, respectively; n, number of plants per plot (harmonic mean). 
Steel \& Torrie (1980), and the Genes software (Cruz, 2001) was used for statistical procedures.

Genetic variance within plot and among plants $\left(\sigma_{\mathrm{d}}^{2}\right)$ were calculated using individual plant data and the means of within variances. The other estimates of variance components were obtained by the mathematical expectation of mean squares (Table 1).

The following genotypic and phenotypic parameters were estimated by the Genes software, calculated from analysis of variance, according to Cruz (2001): genetic variance among progeny, $\hat{\sigma}_{\mathrm{GE}}^{2}=\left(\mathrm{MS}_{1}-\mathrm{MS}_{2}\right) / \mathrm{rp}$; genetic variance within progeny, $\hat{\sigma}_{\mathrm{GD}}^{2}=\left(\theta_{\mathrm{d}} / \theta_{\mathrm{e}}\right) \times\left(\hat{\sigma}_{\mathrm{GE}}^{2}\right)$ (for half-sib progenies $\theta_{\mathrm{d}}=3 / 4$ and $\left.\theta_{\mathrm{e}}=1 / 4\right)$; phenotypic variance within progeny, $\hat{\sigma}_{\mathrm{FD}}^{2}=\hat{\sigma}_{\mathrm{d}}^{2}=\mathrm{MS}_{3}$; mean heritability among progeny, $\quad \hat{\mathrm{h}}_{\mathrm{E}}^{2}=\left(\hat{\sigma}_{\mathrm{GD}}^{2}\right) /\left(\hat{\sigma}_{\mathrm{FD}}^{2}\right) ; \quad$ heritability within progeny, $\hat{\mathrm{h}}_{\mathrm{D}}^{2}=\left(\hat{\sigma}_{\mathrm{GE}}^{2}+\hat{\sigma}_{\mathrm{GD}}^{2}\right) /\left(\hat{\sigma}_{\mathrm{FD}}^{2}+\hat{\sigma}_{\mathrm{e}}^{2}+\hat{\sigma}_{\mathrm{GE}}^{2}\right)$, in which: $\hat{\sigma}_{\mathrm{e}}^{2}$ is the among plot environmental variance $\hat{\sigma}_{\mathrm{e}}^{2}=\left(\mathrm{MS}_{2}-\mathrm{MS}_{3}\right) / \mathrm{r}$; coefficient of experimental

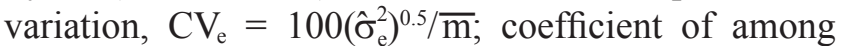
plot experimental variation, $\mathrm{CV}_{\mathrm{ge}}(\%)=100\left(\hat{\sigma}_{\mathrm{GE}}^{2}\right)^{0.5} / \overline{\mathrm{m}}$; coefficient of within-plot experimental variation, $\mathrm{CV}_{\mathrm{gd}}(\%)=100\left(\hat{\sigma}_{\mathrm{GD}}^{2}\right)^{0.5} / \overline{\mathrm{m}}$, where $\mathrm{MS}_{1}$ is the mean squares of progenies; $\mathrm{MS}_{2}$, the mean square among progenies; and $\mathrm{MS}_{3}$, the mean square within progenies; $\mathrm{r}$ and $\mathrm{p}$, the number of repetitions and progenies, respectively; $\hat{\sigma}_{e}^{2}$, the variance of experimental error among plots; $\overline{\mathrm{m}}$, mean.

The gains estimated from direct and indirect selection among and within progenies were calculated, considering selection gains of $10 \%$ among progeny means and within progenies for all the variables, according to Cruz (2001).

For direct selection among progeny: $\mathrm{GS}_{\mathrm{e}}=\mathrm{h}_{\mathrm{m}}^{2} \mathrm{DS}$, and $\mathrm{GS}_{\mathrm{e}}(\%)=100 \mathrm{GS}_{\mathrm{e}} / \overline{\mathrm{X}}_{0}$, in which $\mathrm{GS}_{\mathrm{e}}$ is the selection gain among progenies; $h_{m}^{2}$ is the heritability at progeny mean level, estimated from the matrices of genotypic and phenotypic variance and covariance among progeny means; DS $=\bar{X}_{\mathrm{s}}-\overline{\mathrm{X}}_{0}$ is the selection differential; $\overline{\mathrm{X}}_{0}$ and $\mathrm{X}_{\mathrm{s}}$ are the original mean and mean of the selected individuals, respectively.

For direct selection within progenies: $\mathrm{GS}_{\mathrm{d}}=\mathrm{h}_{\mathrm{i}}^{2} \mathrm{DS}_{\mathrm{m}}$ and $\mathrm{GS}_{\mathrm{d}}(\%)=100 \mathrm{GS}_{\mathrm{d}} /-\overline{\mathrm{X}}_{0}$, in which $\mathrm{GS}_{\mathrm{d}}$ is the selection gain within progenies; $h_{i}^{2}$ is the heritability at plot level (among plants within progenies), estimated from the matrices of genotypic and phenotypic variance and covariance within progenies; and $\mathrm{DS}_{\mathrm{m}}$ is the mean selection differential within the various plots of the selected progenies.
For indirect selection among and within progeny: $\mathrm{GS}_{\mathrm{j}(\mathrm{i})}=\hat{\beta}_{\mathrm{j}(\mathrm{i})} \mathrm{GS}_{\mathrm{i}}$, in which $\mathrm{GS}_{\mathrm{j}(\mathrm{i})}$ is the indirect gain selection on trait $\mathrm{j}$, by selection on trait $\mathrm{i} ; \mathrm{GS}_{\mathrm{i}}$ is the direct selection gain on $\mathrm{i} ; \hat{\beta}_{\mathrm{j}(\mathrm{i})}=\operatorname{Cô} \mathrm{V}_{\mathrm{g}}\left(\mathrm{x}_{\mathrm{i}}, \mathrm{x}_{\mathrm{j}}\right) / \hat{\sigma}_{\mathrm{gi}}^{2}$ is the genetic regression coefficient; $\operatorname{Cô}_{\mathrm{g}}\left(\mathrm{x}_{\mathrm{i}}, \mathrm{x}_{\mathrm{j}}\right)$ is the genetic covariance (among and within) between traits $\mathrm{i}$ and $\mathrm{j}$; $\hat{\sigma}_{\mathrm{gi}}^{2}$ is the genetic variance (among and within progeny) of the main trait on which selection was made.

\section{Results and Discussion}

The effects of mean squares were significant at $1 \%$ probability for all the variables evaluated (Table 2), indicating that the progenies showed genetic variability that led to genetic gain, allowing for the selection of the best progenies. The data obtained were in line with those reported by Moreti et al. (1994), Costa et al. (2000), and Gonçalves et al. (2005) in studies on girth increase, rubber yield, and bark thickness, respectively. The coefficient of experimental variation $(\mathrm{CVe})$ was low for all the variables, ensuring the reliability of the results. The values obtained were coherent to those described by Gonçalves et al. (2005).

Heritability means among progeny were higher than within progeny for all variables (Table 3 ). Consequently, excellent genetic gains could be predicted for selection among progeny from the high $\hat{\mathrm{h}}_{\mathrm{E}}^{2}$ values. Sato et al. (2007), while evaluating Eucalyptus resinifera, also observed $\hat{\mathrm{h}}_{\mathrm{E}}^{2}$ values greater than $\hat{\mathrm{h}}_{\mathrm{D}}^{2}$. According to these authors, the lower values of the $\hat{\mathrm{h}}_{\mathrm{D}}^{2}$ estimate indicate that selection among progeny would be more effective than within progeny, and that the environment greatly influences the manifestation of the variables analyzed. Moreti et al. (1994) reported greater $\hat{h}_{\mathrm{D}}^{2}$ values (0.78) than those found in the present study for rubber yield;

Table 2. Means, mean squares, and coefficient of experimental variation $(\mathrm{CVe})$ for girth, rubber yield, bark thickness, number of latex vessel rings (LV), mean distance between the latex vessel rings (DLR), and mean diameter of the latex vessel rings (DV) of 22 rubber tree progenies.

\begin{tabular}{lrrrrr}
\hline \multirow{2}{*}{ Trait } & \multicolumn{3}{c}{ Mean square } & Mean & \multicolumn{1}{c}{$\begin{array}{l}\text { CVe } \\
(\%)\end{array}$} \\
\cline { 2 - 4 } & Progenies & Among & Within & & \multicolumn{1}{c}{ (\%) } \\
\hline Girth $(\mathrm{cm})$ & $29.46^{* *}$ & 5.22 & 3.63 & 3.58 & 11.14 \\
Rubber yield $\left(\mathrm{g} \mathrm{pl}^{-1}\right)$ & $0.53^{* *}$ & 0.13 & 0.09 & 0.17 & 36.81 \\
Bark thickness $(\mathrm{mm})$ & $13.43^{* *}$ & 2.23 & 2.35 & 3.17 & 3.47 \\
LV (unit) & $8.42^{* *}$ & 1.93 & 2.15 & 2.59 & 5.79 \\
DLR $(\mu)$ & $36,439.48^{* *}$ & $19,108.26$ & $11,210.87$ & 217.09 & 20.14 \\
DV $(\mu)$ & $98.28^{* *}$ & 45.27 & 50.72 & 14.72 & 5.03 \\
\hline
\end{tabular}

**Significant at $1 \%$ probability. 
therefore, in that case, within progeny selection would be more effective than among progeny.

The coefficients of genetic variation within and among progeny showed low values for all variables, except rubber yield, which had high values for both coefficients. According to Baleroni et al. (2003), the coefficient of genetic variation is an important parameter for understanding the genetic structure of a population, since it indicates variation among progeny and allows for the estimation of genetic gains.

The number of latex vessels rings showed the best correlations (Table 4), correlating positively and significantly with girth and bark thickness, but negatively with mean distance among latex vessels rings, which indicates that there were fewer latex vessel rings when the distance between them was greater. Gonçalves et al. (2006), in studies carried out in several locations, reported significant genotypic and phenotypic correlations between rubber yield, girth, and number of latex vessel rings.

For some variables, the genotypic and phenotypic correlations were very low and even negative, but not significant. Therefore, these variables would probably not result in alterations in cases of indirect selection or only in alterations of small magnitude. Gonçalves et al. (1996), while evaluating young progenies, found correlations close to those observed in the present study, for both genotypic and phenotypic correlations.

Genotypic correlations were greater than phenotypic correlations, which were not significant

Table 3. Estimates of genetic parameters for analyses of selection gain among and within progeny for girth, rubber yield, bark thickness, number of latex vessel rings, mean distance between the latex vessel rings (DLR), and mean diameter of the latex vessel rings (DV) of 22 rubber tree progenies.

\begin{tabular}{lccccccc}
\hline Trait & $\sigma_{\mathrm{GE}}^{2}$ & $\hat{\sigma}_{\mathrm{GD}}^{2}$ & $\hat{\sigma}_{\mathrm{FD}}^{2}$ & $\hat{\mathrm{h}}_{\mathrm{E}}^{2}$ & $\hat{\mathrm{h}}_{\mathrm{D}}^{2}$ & CVge & CVgd \\
\hline Girth $(\mathrm{cm})$ & 0.40 & 1.21 & 3.63 & 0.82 & 0.33 & 17.73 & 30.72 \\
Rubber yield $\left(\mathrm{g} \mathrm{pl}^{-1}\right)$ & 0.01 & 0.02 & 0.09 & 0.76 & 0.23 & 49.44 & 85.64 \\
Bark thickness (mm) & 0.19 & 0.56 & 2.35 & 0.83 & 0.24 & 13.64 & 23.63 \\
LV (unit) & 0.11 & 0.32 & 2.15 & 0.77 & 0.15 & 12.68 & 21.96 \\
DLR $(\mu)$ & 288.8 & 886.6 & 210.9 & 0.47 & 0.08 & 7.83 & 13.56 \\
DV $(\mu)$ & 0.88 & 2.65 & 50.71 & 0.54 & 0.05 & 6.38 & 11.06 \\
\hline
\end{tabular}

$\hat{\sigma}_{\mathrm{GE}}^{2}$, genetic variance among progeny; $\hat{\sigma}_{\mathrm{GD}}^{2}$, genetic variance within progenies; $\hat{\sigma}_{\mathrm{FD}}^{2}$, phenotypic variance among and within progenies; $\hat{\mathrm{h}}_{\mathrm{E}}^{2}$, heritability means among progenies; $\hat{\mathrm{h}}_{\mathrm{D}}^{2}$, heritability among and within progenies; CVge (\%), coefficient of genetic variation among progeny; CVgd (\%), coefficient of genetic variation among and within progenies. in any case, indicating that they were not influenced by the environment. Paula et al. (2002), in studies on Eucalyptus camaldulensis, also reported greater genotypic correlations, demonstrating that genetic factors were more important than environmental ones in the expression of at least one of the variables evaluated. According to Vencovsky \& Barriga (1992), genotypic correlation is transitory and found especially in the first generations of populations obtained from the intercrossing of genetically divergent parents.

Selection among and within progenies consists of primarily selecting whole progenies, taking into consideration the deviation of the progeny in relation to the mean phenotypic value of the population. The best individuals are then selected according to the mean phenotypic value of the progeny (Rosado, 2003).

A variation in the percentages of gains among direct and indirect variables was also observed (Table 5). Direct selection gains were greater than indirect ones. According to Falconer (1987), indirect selection can result in greater progress than direct selection, especially if the auxiliary trait has greater heritability than the main trait and if their genetic correlation is of high magnitude. This concept was applied to some variables in the present study, such as girth and rubber yield, bark thickness, and mean distance among latex vessels rings. All of these variables showed high $\hat{\mathrm{h}}_{\mathrm{E}}^{2}$, but greater for girth than for rubber yield, and greater still

Table 4. Estimates of phenotypic (Rf) and genotypic ( $\mathrm{Rg}$ ) correlations for girth, rubber yield, bark thickness, number of latex vessel rings, mean distance between the latex vessel rings (DLR), and mean diameter of the latex vessel rings (DV) of 22 rubber tree progenies.

\begin{tabular}{|c|c|c|c|c|c|c|}
\hline Trait & Correlation & $\begin{array}{c}\text { Rubber } \\
\text { yield }\end{array}$ & $\begin{array}{c}\text { Bark } \\
\text { thickness }\end{array}$ & LV & DRL & DV \\
\hline \multirow{2}{*}{ Girth } & $\mathrm{Rf}$ & 0.075 & 0.273 & 0.058 & 0.040 & 0.003 \\
\hline & $\mathrm{Rg}$ & -0.084 & $0.646^{* *}$ & $0.431 *$ & -0.161 & 0.330 \\
\hline \multirow{2}{*}{$\begin{array}{l}\text { Rubber } \\
\text { yield }\end{array}$} & $\mathrm{Rf}$ & & -0.010 & -0.053 & 0.059 & 0.033 \\
\hline & $\mathrm{Rg}$ & & -0.010 & -0.113 & -0.153 & -0.215 \\
\hline \multirow{2}{*}{$\begin{array}{l}\text { Bark } \\
\text { thickness }\end{array}$} & $\mathrm{Rf}$ & & & 0.305 & 0.045 & 0.104 \\
\hline & $\mathrm{Rg}$ & & & $0.546^{* *}$ & -0.143 & $0.468 *$ \\
\hline \multirow{2}{*}{$\begin{array}{l}\text { Latex } \\
\text { vessel rings }\end{array}$} & $\mathrm{Rf}$ & & & & -0.344 & 0.251 \\
\hline & $\mathrm{Rg}$ & & & & $-0.724 * *$ & $0.616^{* *}$ \\
\hline \multirow{2}{*}{ DLR } & $\mathrm{Rf}$ & & & & & 0.041 \\
\hline & $\mathrm{Rg}$ & & & & & -0.257 \\
\hline
\end{tabular}

$* *$ and $*$ Significant at 1 and 5\% probability, respectively. 
for bark thickness than for the mean distance between latex vessels. The correlations between girth and bark thickness were positive and significant (Table 4).

Indirect selection gains were negative among some variables, indicating that indirect selection of a variable for gain in another was not viable, since there would be loss in the variable selected indirectly. In the case

Table 5. Average of selected individuals $\left(\bar{X}_{\mathrm{s}}\right)$ and selection gains among $\left(\mathrm{GS}_{\mathrm{e}}\right)$, within $\left(\mathrm{GS}_{\mathrm{d}}\right)$, and among and within $\left(\mathrm{GS}_{\mathrm{ed}}\right)$ direct and indirect selection for girth, rubber yield, bark thickness, number of latex vessel rings, mean distance between the latex vessel rings (DLR), and mean diameter of the latex vessel rings (DV) of 22 rubber tree progenies.

\begin{tabular}{|c|c|c|c|c|c|c|}
\hline \multirow[t]{2}{*}{ Variable } & \multicolumn{6}{|c|}{ Response } \\
\hline & Girth & $\begin{array}{c}\text { Rubber } \\
\text { yield }\end{array}$ & $\begin{array}{c}\text { Bark } \\
\text { thickness } \\
\end{array}$ & LV R & DLR & DV \\
\hline & \multicolumn{6}{|c|}{ Selection for girth } \\
\hline$\overline{\mathrm{X}}_{\mathrm{s}}$ & 4.74 & 0.17 & 4.02 & 2.74 & 246.28 & 15.35 \\
\hline $\mathrm{GS}_{\mathrm{e}}(\%)$ & 26.56 & 0.13 & 18.68 & 13.42 & 3.05 & 7.80 \\
\hline $\mathrm{GS}_{\mathrm{d}}(\%)$ & 11.84 & 0.07 & 8.68 & 7.49 & 1.58 & 4.41 \\
\hline $\mathrm{GS}_{\mathrm{ed}}(\%)$ & 26.56 & 3.42 & 22.47 & 4.39 & 6.40 & 2.28 \\
\hline \multirow[t]{2}{*}{ Total gain } & \multicolumn{6}{|c|}{93.38} \\
\hline & \multicolumn{6}{|c|}{ Selection for rubber yield } \\
\hline$\overline{\mathrm{X}}_{\mathrm{s}}$ & 4.12 & 0.31 & 3.66 & 2.65 & 235.31 & 14.65 \\
\hline $\mathrm{GS}_{\mathrm{e}}(\%)$ & 0.04 & 63.25 & 1.55 & 0.84 & 0.52 & -2.08 \\
\hline $\mathrm{GS}_{\mathrm{d}}(\%)$ & 0.05 & 48.79 & 1.90 & 1.16 & 0.68 & -2.95 \\
\hline $\mathrm{GS}_{\mathrm{ed}}(\%)$ & 12.25 & 63.25 & 12.90 & 1.67 & 3.99 & -0.28 \\
\hline \multirow[t]{2}{*}{ Total gain } & \multicolumn{6}{|c|}{105.95} \\
\hline & \multicolumn{6}{|c|}{ Selection for bark thickness } \\
\hline$\overline{\mathrm{X}}_{\mathrm{s}}$ & 4.12 & 0.31 & 3.66 & 2.65 & 235.31 & 14.65 \\
\hline $\mathrm{GS}_{\mathrm{e}}(\%)$ & 0.04 & 63.25 & 1.55 & 0.84 & 0.52 & -2.08 \\
\hline $\mathrm{GS}_{\mathrm{d}}(\%)$ & 0.05 & 48.79 & 1.90 & 1.16 & 0.68 & -2.95 \\
\hline $\mathrm{GS}_{\mathrm{ed}}(\%)$ & 12.25 & 63.25 & 12.90 & 1.67 & 3.99 & -0.28 \\
\hline \multirow{2}{*}{ Total gain } & \multicolumn{6}{|c|}{93.38} \\
\hline & \multicolumn{6}{|c|}{ Selection for number of latex vessel rings } \\
\hline$\overline{\mathrm{X}}_{\mathrm{s}}$ & 4.12 & 0.31 & 3.66 & 2.65 & 235.31 & 14.65 \\
\hline $\mathrm{GS}_{\mathrm{e}}(\%)$ & 0.04 & 63.25 & 1.55 & 0.84 & 0.52 & -2.08 \\
\hline $\mathrm{GS}_{\mathrm{d}}(\%)$ & 0.05 & 48.79 & 1.90 & 1.16 & 0.68 & -2.95 \\
\hline $\mathrm{GS}_{\mathrm{ed}}(\%)$ & 12.25 & 63.25 & 12.90 & 1.67 & 3.99 & -0.28 \\
\hline \multirow[t]{2}{*}{ Total gain } & \multicolumn{6}{|c|}{20.46} \\
\hline & \multicolumn{6}{|c|}{ Selection for distance between latex vessel rings } \\
\hline$\overline{\mathrm{X}}_{\mathrm{s}}$ & 4.12 & 0.31 & 3.66 & 2.65 & 235.31 & 14.65 \\
\hline $\mathrm{GS}_{\mathrm{e}}(\%)$ & 0.04 & 63.25 & 1.55 & 0.84 & 0.52 & -2.08 \\
\hline $\mathrm{GS}_{\mathrm{d}}(\%)$ & 0.05 & 48.79 & 1.90 & 1.16 & 0.68 & -2.95 \\
\hline $\mathrm{GS}_{\mathrm{ed}}(\%)$ & 12.25 & 63.25 & 12.90 & 1.67 & 3.99 & -0.28 \\
\hline \multirow[t]{2}{*}{ Total gain } & \multicolumn{6}{|c|}{-6.13} \\
\hline & \multicolumn{6}{|c|}{ Selection for diameter of the latex vessel rings } \\
\hline $\bar{X}_{\mathrm{s}}$ & 4.12 & 0.31 & 3.66 & 2.65 & 235.31 & 14.65 \\
\hline $\mathrm{GS}_{\mathrm{e}}(\%)$ & 0.04 & 63.25 & 1.55 & 0.84 & 0.52 & -2.08 \\
\hline $\mathrm{GS}_{\mathrm{d}}(\%)$ & 0.05 & 48.79 & 1.90 & 1.16 & 0.68 & -2.95 \\
\hline $\mathrm{GS}_{\mathrm{ed}}(\%)$ & 12.25 & 63.25 & 12.90 & 1.67 & 3.99 & -0.28 \\
\hline Total gain & & & 75. & & & \\
\hline
\end{tabular}

Pesq. agropec. bras., Brasília, v.46, n.9, p.1076-1081, set. 2011 of rubber yield and the mean distance between latex vessels, for example, indirect selection for rubber yield would negatively affect the diameter of the latex vessel rings and vice versa.

When selection is made on a specific variable, it normally results in alterations in another characteristic due to genetic correlations. This phenomenon is called "correlated response to selection" and may or not be of interest to the breeder. Assessment of the magnitude of the correlated response, also called indirect response, is of particular interest in traits with low heritability or which are difficult to measure or identify (Goldenberg, 1968; Martins et al., 2003).

Selection gains among progeny were greater than within progeny for all the variables, as previously observed in the $\hat{h}_{E}^{2}$ and $\hat{h}_{D}^{2}$ values (Table 3 ). When selecting among progenies, the predicted genetic gain is greater, as observed when the mean original values were compared (Table 2) with the selected means (Table 5), in which the latter showed higher values.

Total gains obtained were high, especially for girth increase and rubber yield, with values of 93.38 and $105.95 \%$, respectively. The mean distance between latex vessels rings showed a total negative gain (-6.13), indicating that selection is not recommended or that the method used was not appropriate for selection for this variable.

\section{Conclusions}

1. The progenies show high genetic variability for all the variables analyzed, indicating that selection is favorable in young plants.

2. Selection among progenies promotes higher genetic gains than within progenies, due to the high heritability values observed among progeny.

3. Total genetic gains (direct and indirect) are favorable for rubber yield and girth selection, indicating that the progenies are suitable for future breeding programs.

4. Young progeny selection can maximize the expected genetic gains, thus reducing the rubber tree selection cycle.

\section{Acknowledgments}

To Fundação de Amparo à Pesquisa do Estado de São Paulo, for financial support. 


\section{References}

ADAMS, J.P.; ROUSSEAU, R.J.; ADAMS, J.C. Genetic performance and maximizing genetic gain through direct and indirect selection in cherrybark oak. Silvae Genetica, v.56, p.80-87, 2007.

BALERONI, C.R.S.; ALVES, P.F.; SANTOS, E.B.R. dos; CAMBUIM, J.; ANDRADE, J.A. da C.; MORAES, M.L.T. de. Variação genética em populações naturais de aroeira em dois sistemas de plantio. Revista do Instituto Florestal, v.15, p.125-136, 2003.

COSTA, R.B. da; RESENDE, M.D.V. de; ARAÚJO, A.J. de; GONÇALVES, P.S.; SILVA, M. de A. Maximization of genetic gain in rubber tree (Hevea) breeding with effective size restriction. Genetics and Molecular Biology, v.23, p.457-462, 2000.

CRUZ, C.D. Programa GENES: aplicativo computacional em genética e estatística. Viçosa: UFV, 2001. 648p.

CRUZ, C.D.; REGAZZI, A.J.; CARNEIRO, P.C.S. Modelos biométricos aplicados ao melhoramento genético. 3.ed. Viçosa: UFV, 2004. 480p.

FALCONER, D.S. Introdução à genética quantitativa. Viçosa: UFV, 1987. 279p.

FARIAS NETO, J.T. de; CASTRO, A.W.V. de; BIANCHETTI, A. Aplicação da seleção precoce em famílias de meios-irmãos de taxi-branco. Acta Amazônica, v.33, p.85-91, 2003.

FREITAS, R.G. de; VASCONCELOS, E.S. de; CRUZ, C.D.; ROSADO, A.M.; ROCHA, R.B.; TAKAMI, L.K. Predição de ganhos genéticos em progênies de polinização aberta de Eucalyptus urograndis cultivadas em diferentes ambientes e submetidas a diferentes procedimentos de seleção. Revista Árvore, v.33, p.255-263, 2009.

GOLDENBERG, J. B. El empleo de la correción en el mejoramento genético de las plantas. Fitotecnia Latinoamericana, v.5, p.1-8, 1968.

GONÇALVES, P. de S.; BORTOLETTO, N.; FURTADO, E.L.; SAMBUGARO, R.; BATAGLIA, O.C. Desempenho de clones de seringueira da série IAC 300 selecionados para a região noroeste do Estado de São Paulo. Pesquisa Agropecuária Brasileira, v.36, p.589-599, 2001.

GONÇALVES, P. de S.; CARDINAL, Á.B.B.; COSTA, R.B. da; BORTOLETTO, N.; GOUVÊA, L.R.L. Genetic variability and selection for laticiferous system characters in Hevea brasiliensis. Genetics and Molecular Biology, v.28, p.414-422, 2005.

GONÇALVES, P. de S.; MARTINS, A.L.M.; BORTOLETTO, N.; TANZINI, M.R. Estimates of genetic parameters and correlations of juvenile characters based on open pollinated progenies of Hevea. Brazilian Journal of Genetics, v.19, p.105-111, 1996.

GONÇALVES, P. de S.; SILVA, M. de A.; GOUVÊA, L.R.L.; SCALOPPI JUNIOR, E.J. Genetic variability for girth growth and rubber yield in Hevea brasiliensis. Scientia Agricola, v.63, p.246-254, 2006.

MARTINS, I.S.; CRUZ, C.D.; REGAZZI, A.J.; PIRES, I.E. Eficiência da seleção univariada direta e indireta e de índices de seleção em Eucalyptus grandis. Revista Árvore, v.27, p.327-333, 2003.

MARTINS, I.S.; MARTINS, R.C.C.; CORREIA, H.S. Comparação entre seleção combinada e seleção direta em Eucalyptus grandis, sob diferentes intensidades de seleção. Floresta e Ambiente, v.8, p.36-43, 2001.

MORETI, D.; GONÇALVES, P. de S.; GORGULHO, E.P.; MARTINS, A.L.M.; BORTOLETTO, N. Estimativas de parâmetros genéticos e ganhos esperados com a seleção de caracteres juvenis em progênies de seringueira. Pesquisa Agropecuária Brasileira, v.29, p.1099-1109, 1994.

PAULA, R.C. de; PIRES, I.E.; BORGES, R. de C.G.; CRUZ, C.D. Predição de ganhos genéticos em melhoramento florestal. Pesquisa Agropecuária Brasileira, v.37, p.159-165, 2002.

PRIYADARSHAN, P.M.; GONÇALVES, P.S.; OMOKHAFE, K.O. Breeding Hevea rubber. In: JAIN, S.M.; PRIYADARSHAN, P.M. (Org.). Breeding plantation tree crops: tropical species. New York: Springer, 2009. p.469-522.

REZENDE, G.D.S.P.; BERTOLUCCI, F. de L.G.; RAMALHO, M.A.P. Eficiência da seleção precoce na recomendação de clones de eucalipto avaliados no norte do Espírito Santo e sul da Bahia. Revista Cerne, v.1, p.45-50, 1994.

ROSADO, A.M.M. Seleção entre e dentro de famílias e baseada nos valores genéticos obtidos pelo índice combinado e blup em eucalipto. 2003. 88p. Tese (Doutorado) - Universidade Federal de Viçosa, Viçosa.

SATO, A.S.; SEBBENN, A.M.; MORAES, E.; ZANATO, A.C.S.; FREITAS, M.L.M. Seleção dentro de progênies de Eucalyptus resinifera aos 21 anos de idade em Luiz Antônio-SP. Revista do Instituto Florestal, v.19, p.93-100, 2007.

STEEL, R.G.D.; TORRIE, J.H. Principles and procedures of statistics: a biometrical approach. $2^{\text {nd }}$ ed. New York: Mcgraw-Hill, 1980. 633p.

VENCOVSKY, R.; BARRIGA, P. Genética biométrica no fitomelhoramento. Ribeirão Preto: Sociedade Brasileira de Genética, 1992. 486p.

Received on July 11, 2010 and accepted on September 6, 2011

Pesq. agropec. bras., Brasília, v.46, n.9, p.1076-1081, set. 2011 